Al-Madrasah: Jurnal Ilmiah Pendidikan Madrasah Ibtidaiyah

Vol. 4, No. 2, 2020

DOI 10.35931/am.v4i2.314

P-ISSN: 2620-5807; E-ISSN: 2620-7184

\title{
PENERAPAN METODE PEMBELAJARAN PROBLEM POSING UNTUK MENINGKATKAN KEMAMPUAN SISWA DALAM MEMECAHKAN SOAL CERITA DI SD NEGERI 200010 SIMARDONA
}

\author{
Oleh: \\ Parulian Siregar \\ STAIN Mandailing Natal \\ parulian siregar07@yahoo.com
}

\begin{abstract}
Abstrak
Penelitian ini bertujuan untuk: (1) mengetahui penerapan metode problem posing untuk memecahkan soal cerita, (2) pengaruh metode problem posing terhadap kemampuan siswa dalam memecahkan soal cerita di SD Negeri 200010 Simardona. Penelitian ini menggunakan pendekatan deskriptif kualitatif dan kuantitatif dengan analisis editing data, reduksi data, deskripsi data, dan penarikan kesimpulan. Sedangkan analisi statistik adalah dengan menggunakan progra SPSS 16. Hasil penelitian menunjukkan bahwa: (1) Penerapan metode problem posing di SD Negeri 200010 Simardona sebagai berikut: (a) membuka pembelajaran dengan baik, (b) menjelaskan langkah-langkah metode problem posing dalam memecahkan soal cerita, (c) memberikan kesempatan kepada siswa menanyakan hal-hal yang belum dipahami, (d) memfasilitasi kegiatan belajar siswa dengan memberikan Lembar Kerja Pengajuan Masalah (LKPM), (e) mengarahkan dan membimbing siswa dalam menyusun kalimat sederhana menjadi kalimat tanya dan cara penyelesaiannya, (f) mengarahkan siswa untuk mengajukan soal yang dibentuknya sendiri untuk dijawab siswa lain, (g) mengarahkan dan membimbing beberapa siswa untuk menanggapi dan menjawab pertanyaan yang diajukan siswa, (h) melakukan umpan balik dan tanggapan terhadap pengajuan masalah yang telah dilakukan, (i) melakukan tanya jawab tentang kesulitan-kesulitan siswa dalam mengajukan masalah, (j) menutup pembelajaran dengan baik. (2) Metode problem posing berpengaruh positif terhadap kemampuan siswa dalam memecahkan soal cerita yang di SD Negeri 200010 Simardona
\end{abstract}

Al-Madrasah: Jurnal Ilmiah Pendidikan Madrasah Ibtidaiyah Vol. 4, No. 1, Januari-Juni 2020 
Parulian Siregar: Penerapan Metode Pembelajaran Problem Posing Untuk Meningkatkan Kemampuan Siswa Dalam Memecahkan Soal Cerita Di SD Negeri 20010 Simardona

dipengaruhi metode problem posing adalah sebesar 28\% dan sisanya dipengaruhi oleh faktor lainnya sebesar $72 \%$.

Kata Kunci: Problem Posing, Soal cerita, 2020

\section{A. Pendahuluan}

Pembelajaran soal cerita yang mengandung operasi bilangan merupakan bagian dari pokok pembahasan matematika pada pendidikan dasar. ${ }^{1}$ Dalam konteks matematika, soal cerita adalah soal yang diuraikan dengan serangkaian kalimat dalam bentuk cerita berdasarkan pengalaman sehari-hari yang berkaitan dengan konsepkonsep matematika. ${ }^{2}$ Untuk menyelesaikan soal cerita, tentunya dibutuhkan suatu daya nalar yang kritis, kreatif dan tinggi, sebab dalam soal cerita selalu berkaitan dengan ide-ide, konsep-konsep yang abstrak. Dikatakan abstrak, karena kalimat matematika yang terkandung di dalam soal cerita masih belum terlihat secara konkrit sehingga perlu diterjemahkan kedalam kalimat matematika untuk lebih mudah dipecahkan.

Berbagai kesulitan yang dihadapi oleh siswa dalam menyelesaikan soal cerita yang mengandung operasi bilangan, diantaranya adalah terletak pada mengaitkan keadaan yang ada di dalam soal cerita dengan kalimat matematika, memahami konsep matematikanya dan menerjemahkannya kedalam kalimat-kalimat matematika. Rahardjo \& Waluyati menyatakan bahwa lebih dari 50\% guru menyatakan bahwa sebagian besar siswa mengalami kesulitan dalam menyelesaikan soal cerita, letak kesulitan tersebut berada pada kurangnya keterampilan siswa dalam menerjemahkan kalimat seharihari (soal cerita) ke dalam kalimat matematika. ${ }^{3}$

Banyak faktor yang mempengaruhi rendahnya kemapuan siswa dalam menyelesaikan soal cerita di SD Negeri 200010 Simardona,

${ }^{1}$ Elwin Lusmadi. 2006. Matematika Untuk Sekolah Dasar Kelas III, (t.k: Citra Cemara, 2006), h. 12.

${ }^{2}$ Endang Setyo Winarni \& Sri Harmini, Matematika Untuk PGSD, (Bandung: Remaja Rosdakarya, 2011), h. 122

3 Marsudi Rahardjo \& Astuti Waluyati, Pembelajaran Sosal Cerita Operasi Hitung Campuran di Sekolah Dasar. (Yogyakarta: Pusat Pengembangan dan Pemberdayaan Pendidik dan Tenaga Kependidikan Matematika, 2011) h. 1 
Parulian Siregar: Penerapan Metode Pembelajaran Problem Posing Untuk Meningkatkan Kemampuan Siswa Dalam Memecahkan Soal Cerita Di SD Negeri 20010 Simardona

salah satunya adalah dapat diasumsikan karena kurang efektifnya metode pembelajaran yang digunakan oleh guru, sebab salah satu yang menentukan keberhasilan pembelajaran adalah metode dan strategi yang digunakan guru itu sendiri. Hamzah \& Mohamad mengatakan bahwa "keberhasilan pencapaian kompetensi salah satu mata pelajaran bergantung pada beberapa aspek, salah satu adalah bagaimana cara (metode) seorang guru dalam melaksanakan pembelajaran"4. Slameto menyatakan bahwa pembelajaran sangat ditentukan oleh metode mengajar dan belajar yang efisien apabila dapat menggunakan metode mengajar yang tepat. ${ }^{5}$ Oleh karena itu, dalam pemecahan soal cerita perlu ada suatu metode pembelajaran yang dapat membantu metode yang lain untuk meningkatkan kemampuan siswa dalam memecahkan soal cerita.

Salah satu metode pembelajaran yang dapat digunakan dalam pembelajaran soal cerita yang mengandung operasi bilangan adalah metode pembelajaran problem posing. Metode ini dikembangkan oleh Lyn D. English tahun 1997 pada awalnya diterapkan pada pembelajaran matematika, pada perkembangannya digunakan pada pembelajaran yang lainnya. ${ }^{6}$ Metode problem posing adalah proses pembelajaran yang meliputi aktivitas membuat masalah dari masalah yang diberikan, membuat strategi untuk menyelesaikan masalah baru dan mengaitkan informasi berdasarkan permasalahan yang telah diberikan. $^{7}$ Dengan adanya pembelajaran problem posing akan

${ }^{4}$ Hamzah B. Uno \& Mohamad, Nurdin, Belajar dengan Pendekatan PAILKEM: Pembelajaran, Aktif, Inovatif, Lingkungan, Kreatif, Efektif, Menarik, (Jakarta: Bumi Aksara, 2011), h. 75

${ }^{5}$ Slameto, Belajar dan Faktor-Faktor Yang Mempengaruhinya, (Jakarta: Rineka Cipta, 2010), h. 76.

${ }^{6}$ Muhammad Thobroni \& Arif Mustofa, Belajar \& Pembelajaran: Pengembangan wacana dan Praktik Pembelajaran dalam Pembengunan Nasional, (Jogjakarta: ArRuzz Media, 2011), h. 351

${ }^{7}$ Ketut Sutame, Implementasi Pendekatan Problem Posing Untuk Meningkatkan Kemampuan Penyelesaian Masalah, Berpikir Kritis Serta Mengeliminir Kecemasan Matematika. Makalah Dipresentasikan Dalam Seminar Nasional Matematika Dan Pendidikan Matematika Dengan Tema "Matematika dan Pendidikan Karakter Dalam Pembelajaran" pada tanggal 3 Desember 2011. Pendidikan Matematika FMIPA UNY, 978-979-16353-6-3. (FMIPA UNY Yogjakarta, 2011), h, 311. 
menyebabkan terbentuknya pemahaman konsep yang lebih mantap pada diri siswa terhadap materi yang telah diberikan.

Silver dalam Irwan menjelaskan bahwa Problem posing merupakan; (1) perumusan soal sederhana atau perumusan ulang soal yang ada dengan beberapa perubahan agar lebih sederhana dan dapat dipahami dalam rangka memecahkan soal yang rumit, (2) permusan soal yang berkaitan dengan syarat-syarat pada soal yang telah diselesaikan dalam rangka mencari alternatif pemecahan lain, dan (3) perumusan soal dari informasi dan situasi yang diberikan ${ }^{8}$. Dalam penelitian ini, problem posing diartikan sebagai aktivitas pembelajaran yang meminta siswa secara individu untuk mengajukan atau membuat soal atau masalah matematika dan penyelesaiannya berdasarkan informasi/soal cerita yang diberikan guru (presolution posing). Dengan demikian perlu diakukan penelitian untuk mengetahui bagaimana guru menerapkan metode ini dalam pembelajaran untuk meningkatkan kemampuan siswa.

\section{B. Kajian Pustaka}

1. Metode Pembelajaran Problem Posing

Problem posing terdiri dari dua kata yaitu "problem" artinya masalah dan "posing" yang berasal dari kata "pose" artinya mengajukan atau membuat, berarti problem posing adalah mengajukan atau membuat masalah/soal. Banyak para ahli yang memberikan istilah problem posing dalam bentuk bahasa Indonesia, diantaranya adalah: Suryanto (1999) dan As'ari (2004) dengan mengistilahkan pembentukan soal, Sutiasro (1999) dengan sebutan membuat soal, Siswono (1999) dengan menggunakan istilah pengajuan soal, dan Suharta (2000) menggunakan istilah pengkonstruksian masalah. ${ }^{9}$ Metode ini baru dikembangkan oleh Lyn D. English pada tahun 1997 dan awal mulanya diterapkan pada

${ }^{8}$ Irwan, Pengaruh Pendekatan Promlem Posing Model Search, solve, Create and Share (SSCS) Dalam Upaya Meningkatkan Kemampuan Penalaran Matematis Mahasiswa Matematika: Sebuah Kajian Eksprimen pada Jurusan Matematika FMIPA Universitas Negeri Padang (UNP), Jurnal Penelitian Pendidikan, 12 (2), 2. (Padang: FMIPA UNP, 2011), h. 3

9 Suprayitno, Pembelajaran Soal Cerita... h. 13 
Parulian Siregar: Penerapan Metode Pembelajaran Problem Posing Untuk Meningkatkan Kemampuan Siswa Dalam Memecahkan Soal Cerita Di SD Negeri 20010 Simardona

pembelajaran matematika, kemudian pada perkembangannya diimplementasikan pada pembelajaran lainnya seperti psika, IPA dan sebagainya. ${ }^{10}$

Problem posing dapat dimaknai sebagai: (a) menyederhanakan soal yang rumit dengan beberapa perubahan dari bentuk aslinya agar lebih sederhana dan mudah dipahami, (b) perumusan soal yang berkaitan dengan syarat-syarat pada soal yang telah dipecahkan dalam rangka mencari alternatif pemecahan lain sebagai langkah problem solving yang telah dilakukan (c) merumuskan atau membuat soal dari informasi dan situasi yang diberikan. ${ }^{11}$ Silver dalam Deborah memberikan istilah problem posing dengan tiga bentuk aktivitas matematika yaitu: (a) Pengajuan pre-solusi (presolution posing), yaitu membentuk atau membuat soal dari informasi/data yang diberikan, (b) pengajuan didalam solusi (within-solution posing), yaitu seorang peserta didik merumuskan kembali soal seperti yang telah diselesaikan, (c) pengajuan setelah solusi (post solution posing), yaitu memodifikasi tujuan atau kondisi soal yang sudah diselesaikan untuk membuat soal yang baru. ${ }^{12}$ Abu Elwan mengklasifikasikan problem posing menjadi tiga yaitu problem posing bebas, problem posing semi terstruktur dan problem posing terstruktur.

Diantara kelebihannya metode problem posing adalah (a) membantu siswa dalam mengembangkan keyakinan dan kesukaan terhadap metematika, (b) sarana komunikasi matematika siswa baik secara reseptif maupun ekspresif, (c) merangsang peningkatan kemampuan matematika siswa, (d) mengarahkan siswa pada sikap kritis dan kreatif, (e) mempertajam pemahaman soal, (f) meningkatkan kemampuan penalaran matematis mahasiswa, sebab pada pembelajaran tercipta suasana pembelajaran yang lebih kondusif, aktivitas dan kerja sama yang mengikat, (g) meningkatkan minat dan

${ }^{10}$ Muhammad Thobroni \& Arif Mustofa, Belajar \& Pembelajaran ... h. 351.

${ }^{11}$ Irwan, Pengaruh Pendekatan Promlem Posing Model Search, solve, Create and Share... h. 3 .

12 Deborah Jean Priest, Problem-Posing Intervertion In The Development Of Problem-Solving Conpetence Of Underachieving, Middle-Year Students. Thesis tidak terbitkan. (Brisbane: Faculty of Education queensland University of Technology Kelvin Grove Campus, 2009) h. 66.

Al-Madrasah: Jurnal Ilmiah Pendidikan Madrasah Ibtidaiyah Vol. 4, No. 2, Januari-Juni 2020 
motivasi siswa dalam belajar matematika serta lebih mudah memahami soal karena dibuat sendiri. Sedangkan diantara kelemahannya adalah: (a) siswa seringkali mengadakan penipuan, siswa hanya meniru dan menyalin hasil pekerjaan temannya, tanpa mengalami peristiwa belajar, (b) membutuhkan waktu yang lebih banyak bagi pendidik, khususnya waktu memeriksa jawaban atau hasil tugas siswa dan sebagainya.

Pentingnya penerapan problem posing dalam pembelajaran matematika telah disampaikan dalam kurikulum pendidikan matematika di Amerika yaitu National Cuoncil for Teachers of Mathematics. Pada kurikulum tersebut merekomendasikan agar siswa diberi kesempatan yang banyak untuk investigasi dan merumuskan soal atau pertanyaan dari situasi maslah. ${ }^{13}$ English dan Brown menjelaskan bahwa problem posing sangat penting dalam pembelajaran matematika, sebab di dalamnya terdapat inti dari aktivitas matematika, termasuk aktivitas siswa dalam membangun masalah sendiri serta menyelesaikannya sendiri dengan bimbingan guru. ${ }^{14}$ Dengan demikian, dalam pembelajaran matematika siswa tidak hanya dituntut untuk dapat memecahkan beberapa pertanyaan dari masalah yang ada, tetapi juga dituntut untuk mampun membentuk pertanyaan dari informasi yang ada (problem posing).

Arifin menjelaskan bahwa langkah-langkah pembelajaran dengan menggunakan metode problem posing dapat dilakukan sebagai berikut: (a) guru menyampaikan kompetensi yang akan dicapai dalam pembelajaran, (b) siswa dibagi dalam beberapa kelompok, (c) setiap kelompok merangkum materi yang berbeda yang masih dalam satu konsep pembelajaran, (d) hasil rangkuman ditulis di lembar kerja siswa dalam bentuk peta konsep, (e) masing-masing kelompok membuat pertanyaan dari hasil rangkuman (problem pising I), (f) setiap kelompok mendiskusikan dan memecahkan pertanyaan yang dibuat setiap anggota kelompok, (g) setiap kelompok menulis dua

${ }^{13}$ Tatag Yuli Eko Siswono, Pengajuan Soal (Problem Posing) Oleh Siswa Dalam Pembelajaran Geometri di SLTP, Makalah ini disampaikan pada Seminar Nasional Matematika "Peran Matematika Milenium III", ITS Surabaya, 2 Nopember 2000, h. 8

${ }^{14}$ Irwan, Pengaruh Pendekatan Promlem Posing Model Search, solve, Create and Share... h. 2 
pertanyaan yang sulit diselesaikan pada lembar kerja (problem posing II), (h) setiap kelompok mempresentasikan rangkuman jawaban dari pertanyaan yang sulit dan membacakan perntanyaan yang belum terjawab, (i) kelompok lain sebagai audiens membantu memberikan jawaban terhadap pertanyaan yang belum terjawab, (j) selama diskusi kelompok atau antara kelompok, guru bertindak sebagai moderator, fasilitator, pengarah dan pembimbing terhadap berlangsungnya pembelajaran dan $(\mathrm{k})$ guru memberikan jawajan terhadap soal yang belum terselesaikan siswa dan membantu siswa dalam menarik kesimpulan mulai dari yang sederhana sampai ke hal-hal yang kompleks. ${ }^{15}$

\section{Pemecahan Soal Cerita Yang Mengandung Operasi Bilangan} Dengan Metode Problem Posing

Kemapuan dalam memecahkan soal cerita merupakan kompetensi yang sangat diharapkan dimiliki oleh setiap siswa karena pada tingkat pendidikan dasar (SD/MI) sering kali ditemui soal-soal yang berbentuk cerita, khususnya pada mata pelajaran matematika. Dalam menyelesaikan soal cerita tersebut siswa harus mampu mengoperasi penjumlahan dan pengurangan dengan benar. Dengan demikian, pemecahan soal cerita yang dimaksud dalam penelitian ini adalah kemampuan siswa dalam menyelesaikan/mengoperasi penjumlahan dan pengurangan didalam soal cerita dengan baik dan benar. Problem posing merupakan salah satu metode pembelajaran yang dapat mempengaruhi kemampuan siswa dalam memecahkan soal cerita. Adapun aspek problem posing yang mempengaruhi kemampuan pemecahkan soal cerita antara lain adalah: (a) spek pembentukan soal, (b) aspek melatih berpikir kritis dan kreatif dan spek pemahaman konsep.

Ada dua pendekatan yang dapat dilakukan dalam menyelesaikan soal cerita yaitu pendekatan model dan pendekatan penterjemahan kedalam kalimat matematika. Pendekatan model adalah pendekatan yang menuntut siswa membaca dan mendengarkan soal cerita, kemudian siswa mencocokkan situasi yang dihadapi itu

\footnotetext{
${ }^{15}$ Arifin, Kompetensi guru... h. 73
} 
dengan model yang sudah dipelajari sebelumnya. Sedangkan pendekatan penterjemahan adalah melibatkan siswa pada kegiatan membaca kata demi kata dan ungkapan demi ungkapan dari soal cerita yang sedang dihadapinya untuk kemudian menerjemahkan kata-kata dan ungkapan tersebut kedalam kalimat matematika. ${ }^{16}$

\section{Metode Penelitian}

Pendekantan yang digunakan dalam penelitian ini adalah pendekatan deskriptif kualitatif dan pendekatan kuantitatif. Deskriptif kualitatif yang dimaksud dalam penelitian ini adalah suatu usaha yang dilakukan oleh peneliti untuk menggambarkan bagaimana penerapan problem posing dalam memecahkan soal cerita yang mengandung operasi bilangan penjumlahan dan pengurangan pada kelas V SD Negeri 200010 Simardona. Pendekatan kuantitatif yang dimaksud dalam penelitian ini adalah menggunakan pendekatan. Adapun subjek penelitian ini adalah siswa kelas V SD Negeri 200010 Simardona berjumlah 23 orang. Adapun analisis data yang akan dilakukan adalah sebagai berikut: (1) analisis deskriptif kualitatif adalah upaya yang dilakukan untuk menganalisis data tentang bagaimana penerapan metode problem posing pada kelas V SD Negeri 200010 Simardona dengan langkah-langkah editing data, reduksi data, deskripsi data dan Penarikan kesimpulan. (2) analisis statistik yang diulakukan dengan menggunakan program windows SPSS versi 16.

\section{Hasil dan Pembahasan Penelitian}

1. Penerapan Metode Pembelajaran Problem Posing Di V SD Negeri 200010 Simardona.

Adapun penerapan metode problem posing di V SD Negeri 200010 Simardona adalah sebagai berikut: (a) membuka pembelajaran dengan baik, (b) menjelaskan langkah-langkah metode pembelajaran problem posing dalam memecahkan soal cerita dengan memberikan contoh pengajuan pertanyaan dari soal cerita, (c) memberikan kesempatan kepada siswa menanyakan yang belum dipahami tentang

\footnotetext{
${ }^{16}$ Endang setyo Winarni \& Sri Harmini, Matematika ... h. 122-123.
} 
pengajuan masalah atau pembentukan soal, (d) memfasilitasi kegiatan belajar dengan memberikan Lembar Kerja Pengajuan Masalah (LKPM) kepada masing-masing siswa, (e) mengarahkan dan membimbing siswa dalam mengerjakan Lembar Kerja Pengajuan Masalah (LKPM) yaitu: menyusun kalimat sederhana menjadi kalimat tanya, pengajuan soal dan cara penyelesaiannya, (f) mengarahkan siswa untuk mengajukan soal yang dibentuknya sendiri untuk dijawab siswa lain, (g) mengarahkan dan membimbing beberapa siswa untuk menanggapi dan menjawab pertanyaan yang diajukan siswa, (h) melakukan umpan balik dan tanggapan terhadap pengajuan masalah yang telah dilakukan, (i) melakukan tanya jawab tentang kesulitankesulitan siswa dalam mengajukan masalah, (j) menutup pembelajaran dengan baik. Keefektifan pembelajaran dengan metode problem posing disebabkan karena setiap siswa dituntut untuk dapat membentuk soal dari informasi yang ada dengan bahasanya sendiri secara mandiri dan siswa selalu dilatih untuk berhadapan dengan masalah nyata yang dicoba dipecahkan oleh setiap siswa dengan bimbingan dan arahan guru.

2. Pengaruh Metode Pembelajaran Problem Posing Terhadap

Kemampuan Siswa Dalam Memecahkan Soal Cerita di V SD Negeri 200010 Simardona.

Berdasarkan uji signifikansi yang telah dilakukan di V SD Negeri 200010 Simardona adalah sebesar 0,035 < 0,05, sehingga Ho ditolak, artinya metode problem posing berpengaruh positif terhadap kemampuan siswa dalam memecahkan soal cerita yang mengandung operasi bilangan. Untuk melihat seberapa besar pengaruh metode problem posing terhadap kemampuan siswa dapat dilakukan nilai $\mathrm{R}$ Square $\times 100 \%=0,280 \times 100 \%=28 \%$, artinya metode problem posing memberikan kontribusi terhadap kemampuan siswa dalam memecahkan soal cerita sebesar $28 \%$ dan sisanya dipengaruhi oleh factor lain yaitu sebesar $72 \%$. Dari konstanya adalah sebesar 47,325 , artinya jika metode problem posing nilainya adalah 1, maka kemampuan siswa dalam memecahkan soal cerita adalah nilainya positif yaitu sebesar 47,325. Sedangkan koefisien regresi variabel metode problem posing sebesar 0,490 ; artinya jika metode problem posing mengalami kenaikan sebesar 1 , maka kemampuan siswa dalam 
memecahkan soal cerita yang mengandung operasi bilangan penjumlahan dan pengurangan akan mengalami peningkatan sebesar 0,490 .

Hasil penelitian juga menunjukkan bahwa kemampuan siswa dalam memecahkan soal cerita yang mengandung operasi bilangan penjumlahan dan pengurangan setelah menggunakan metode pembelajaran problem posing lebih baik daripada sebelum menggunakan metode pembelajaran problem posing. Temuan ini didukung oleh perolehan nilai rata-rata kelas III V SD Negeri 200010 Simardona setelah menggunakan metode pembelajaran problem posing sebesar $69,37 \%$ dan sebelum menggunakan metode pembelajaran problem posing sebesar $45 \%$. Berdasarkan kelompok, nilai rata-rata kelompok tinggi sebelum menggunakan metode problem posing sebesar $70 \%$ dan sesudah sebesar $92,5 \%$ dengan perbedaan sebesar $22,5 \%$ lebih tinggi sesudah menggunakan metode problem posing. Nilai rata-rata kelompok sedang sebelum menggunakan metode problem posing sebesar 42,5\% dan sesudah menggunakan metode problem posing sebesar 66,25 \% dengan perbedaan sebesar $23,75 \%$ lebih tinggi sesudah menggunakan metode problem posing. Nilai rata-rata kelompok rendah sebelum menggunakan metode problem posing sebesar $25 \%$ dan sesudah menggunakan metode problem posing sebesar 52,5 \% dengan perbedaan sebesar $25,5 \%$ lebih tinggi sesudah menggunakan metode problem posing.

Pencapaian nilai yang tinggi pada pembelajaran problem posing ini disebabkan karena pada pembelajaran problem posing siswa dilatih untuk mengajukan atau membuat soal kemudian menyelesaikan soal yang dibuat oleh siswa lain. Hasil ini dikarenakan pada kegiatan presolution posing siswa dilatih untuk dapat mengaitkan informasi/situasi yang mereka peroleh dengan materi yang sudah mereka pelajari. Dari uraian di atas dapat memjadi landasan emprik metode problem posing sebagai salah satu metode yang efektif diterapkan dalam pembelajaran, khususnya dalam memecahkan soal cerita yang mengandung operasi bilangan penjumlahan dan pengurangan. 
Parulian Siregar: Penerapan Metode Pembelajaran Problem Posing Untuk Meningkatkan Kemampuan Siswa Dalam Memecahkan Soal Cerita Di SD Negeri 20010 Simardona

\section{E. Kesimpulan}

Berdasarkan hasil analisis data dan pembahasan yang telah dilakukan, maka diperoleh beberapa kesimpulan sebagai berikut: (a) Penerapan metode problem posing dengan tipe presolution posing dalam proses pembelajaran di V SD Negeri 200010 Simardona adalah sebagai berikut: (a) membuka pembelajaran dengan baik, (b) menjelaskan langkah-langkah metode pembelajaran problem posing dalam memecahkan soal cerita dengan memberikan contoh pengajuan pertanyaan dari soal cerita, (c) memberikan kesempatan kepada siswa menanyakan yang belum dipahami tentang pengajuan masalah atau pembentukan soal, (d) memfasilitasi kegiatan belajar dengan memberikan Lembar Kerja Pengajuan Masalah (LKPM) kepada masing-masing siswa, (e) mengarahkan dan membimbing siswa dalam mengerjakan Lembar Kerja Pengajuan Masalah (LKPM) yaitu: menyusun kalimat sederhana menjadi kalimat tanya, pengajuan soal dan cara penyelesaiannya, (f) mengarahkan siswa untuk mengajukan soal yang dibentuknya sendiri untuk dijawab siswa lain, $(\mathrm{g})$ mengarahkan dan membimbing beberapa siswa untuk menanggapi dan menjawab pertanyaan yang diajukan siswa, (h) melakukan umpan balik dan tanggapan terhadap pengajuan masalah yang telah dilakukan, (i) melakukan tanya jawab tentang kesulitan-kesulitan siswa dalam mengajukan masalah, (j) menutup pembelajaran dengan baik.

Berdasarkan uji hipotesis yang dilakukan bahwa nilai probabilitas (sig) uji regresi di V SD Negeri 200010 Simardona adalah $0,035<0$, ini artinya metode problem posing berpengaruh positif terhadap kemampuan siswa dalam memecahkan soal cerita yang mengandung operasi bilangan di V SD Negeri 200010 Simardona. Adapun kemampuan siswa di V SD Negeri 200010 Simardona dipengaruhi metode problem posing adalah sebesar 28\% (kategari sedang) dan sisanya dipengaruhi oleh factor lain yaitu sebesar $72 \%$. 
Parulian Siregar: Penerapan Metode Pembelajaran Problem Posing Untuk Meningkatkan Kemampuan Siswa Dalam Memecahkan Soal Cerita Di SD Negeri 20010 Simardona

\section{Daftar Pustaka}

Arikunto, Suharsini. 2010. Prosedur Penelitian Suatu pendekatan praktik, Jakarta: Rineka Cipta.

Deborah Jean Priest, 2009. Problem-Posing Intervertion In The Development Of Problem-Solving Conpetence Of Underachieving, Middle-Year Students. Thesis tidak terbitkan. Brisbane: Faculty of Education queensland University of Technology Kelvin Grove Campus.

Elwin Lusmadi, 2006. Matematika Untuk Sekolah Dasar Kelas III, t.k: Citra Cemara.

Endang setyo Winarni \& Sri Harmini, 2011. Matematika Untuk PGSD, Bandung: Remaja Rosdakarya.

Hamzah B. Uno \& Mohamad, Nurdin, 2011. Belajar dengan Pendekatan PAILKEM: Pembelajaran, Aktif, Inovatif, Lingkungan, Kreatif, Efektif, Menarik, Jakarta: Bumi Aksara.

Irwan, 2011. Pengaruh Pendekatan Promlem Posing Model Search, solve, Create and Share (SSCS) Dalam Upaya Meningkatkan Kemampuan Penalaran Matematis Mahasiswa Matematika: Sebuah Kajian Eksprimen pada Jurusan Matematika FMIPA Universitas Negeri Padang (UNP), Jurnal Penelitian Pendidikan, 12 (2), 2. Padang: FMIPA UNP.

Ketut Sutame, 2011. Implementasi Pendekatan Problem Posing Untuk Meningkatkan Kemampuan Penyelesaian Masalah, Berpikir Kritis Serta Mengeliminir Kecemasan Matematika. Makalah Dipresentasikan Dalam Seminar Nasional Matematika Dan Pendidikan Matematika Dengan Tema "Matematika dan Pendidikan Karakter Dalam Pembelajaran" pada tanggal 3 Desember 2011. Pendidikan Matematika FMIPA UNY, 978-97916353-6-3. FMIPA UNY Yogjakarta.

Marsudi Rahardjo \& Astuti Waluyati, 2011. Pembelajaran Sosal Cerita Operasi Hitung Campuran di Sekolah Dasar. Yogyakarta: Pusat Pengembangan dan Pemberdayaan Pendidik dan Tenaga Kependidikan Matematika, 2011.

Moleong, Lexy J. 2005. Metode Penelitian Kualitatif, Bandung: Remaja Rosdakarya. 
Parulian Siregar: Penerapan Metode Pembelajaran Problem Posing Untuk Meningkatkan Kemampuan Siswa Dalam Memecahkan Soal Cerita Di SD Negeri 20010 Simardona

Muhammad Thobroni \& Arif Mustofa, 2011., Belajar \& Pembelajaran: Pengembangan wacana dan Praktik Pembelajaran dalam Pembengunan Nasional, Jogjakarta: Ar-Ruzz Media.

Slameto, 2010. Belajar dan Faktor-Faktor Yang Mempengaruhinya, Jakarta: Rineka Cipta.

Sugiyono. 2011. Statistik untuk penelitian, Bandung: Alfabeta.

Sukmadinata, Nana Syaodih. 2011, Metode penelitian pendidikan, Bandung: Remaja Rosdakarya.

Suprayitno, 2004. Pembelajaran soal cerita operasi hitung campuran dengan pendekatan problem posing pada siswa kelas $V$ sekolah dasar. Tesis, tidak diterbitkan. Malang: Program Pascasarjana UM Malang.

Tatag Yuli Eko Siswono, 2000. Pengajuan Soal (Problem Posing) Oleh Siswa Dalam Pembelajaran Geometri di SLTP, Makalah ini disampaikan pada Seminar Nasional Matematika "Peran Matematika Milenium III", ITS Surabaya.

Trihendradi. 2011 C. Langkah mudah melakukan analisis statistic menggunakan SPSS 16, Yogjakarta: Andi.

Al-Madrasah: Jurnal Ilmiah Pendidikan Madrasah Ibtidaiyah

Vol. 4, No. 2, Januari-Juni 2020 
Parulian Siregar: Penerapan Metode Pembelajaran Problem Posing Untuk Meningkatkan Kemampuan Siswa Dalam Memecahkan Soal Cerita Di SD Negeri 20010 Simardona

Al-Madrasah: Jurnal Ilmiah Pendidikan Madrasah Ibtidaiyah Vol. 4, No. 2, Januari-Juni 2020 